\title{
RANCANG BANGUN MESIN PENETAS TELUR TENAGA HYBRID
}

\author{
I Wayan Sugita, Fikri Firmansah, Rakhmat Sobirin, Muhammad Raihan Ardianto \\ Program Studi Teknik Mesin, Fakultas Teknik, Universitas Negeri Jakarta \\ Jalan Rawamangun Muka, Rawamangun, Jakarta Timur 13220 \\ Korespondensi: wayan-sugita@unj.ac.id
}

\begin{abstract}
Abstrak
Mesin penetas telur pada umumnya hanya menggunakan satu sumber energi yaitu energi listrik dari PLN. Dalam penelitian ini dibuat mesin penetas telur menggunakan dua sumber energi yaitu tenaga listrik PLN pada waktu malam hari dan tenaga panas matahari pada waktu siang hari. Kapsitas dari mesin penetas yang dibuat adalah 100 butir telur. Dalam proses rancang bangun mesin penetas telur dengan sumber energi hybrid mempunyai beberapa tahap yaitu diawali dengan tahap pembuatan sketsa gambar sederhana, gambar kerja, perhitungan sumber panasnya, proses pembuatan, instalasi kelistrikannya, serta uji coba kestabilan temperatur. Dari hasil pengujian Mesin Penetas Telur Tenaga Hybrid ini, suhu stabil antara $37^{\circ}-38^{\circ} \mathrm{C}$ dengan daya yang digunakan sebesar 20 watt.
\end{abstract}

Kata kunci : Rancang Bangun, Mesin Penetas Telur, Tenaga Hybrid

\section{PENDAHULUAN}

Seiring perkembangan dan pertumbuhan penduduk di Indonesia maka berdampak pada meningkatnya konsumsi masyarakat, khususnya akan kebutuhan daging unggas maupun telurnya yang kaya akan sumber protein utama, maka harus dimbangi dengan persediaan yang cukup untuk memenuhi ketersediaan pangan yang mengandung protein yang tinggi tetap terpenuhi. Berdasarkan data BPS rata-rata konsumsi nasional perkapita pada tahun 2017: daging ayam $0,124 \mathrm{~kg}$, telur ayam 2,119 kg dan telur itik 0,04 butir [1].

Ayam merupakan komoditas peternakan yang sangat disukai oleh masyarakat, dimana jika dibandingkan dengan ternak lain, namun ternak ini mempunyai produktivitas masih rendah sebagai akibat dari pemeliharaan yang masih sederhana dan belum memperhatikan tata laksana atau manajemen pemeliharaan yang baik, pemberian pakan yang belum seimbang baik kualitas maupun kuantitasnya [2]. Penetasan telur dapat dilakukan dengan dua cara yaitu penetasan alami dan penetasan buatan [3-4]. Pengeraman telur secara alami sepenuhnya dilakukan oleh induk ayam itu sendiri, sedangkan penetasan buatan dilakukan dengan menggunakan alat yang disebut mesin tetas atau incubator [5]. Penetasan alami kurang efektif dalam menetaskan telur karena satu induk hanya bisa mengerami sekitar 10 butir telur, sedangkan penetasan buatan mampu menetaskan jumlah telur dalam jumlah ratusan bahkan ribuan butir, tergantung kapasitas tampung mesin tetas [6]. Dewasa ini sudah dikembangkan mesin tetas dengan penambahan konveyor untuk membantu proses distribusi panas pada telur [7].

Terdapat lima hal yang harus diperhatikan pada ruang mesin tetas yaitu temperatur, kelembaban udara, ventilasi, pemutaran telur dan kebersihan [8]. Suhu dan oksigen $\left(\mathrm{O}_{2}\right)$ embrio dianggap sebagai faktor penting mempengaruhi perkembangan embrio, daya tetas, dan performa setelah menetas [9-10]. Embrio sangat sensitif terhadap suhu penetasan yang lebih rendah atau lebih tinggi, suhu penetasan yang lebih rendah akan memperlambat dan semakin tinggi suhu inkubasi akan mempercepat pertumbuhan dan perkembangan embrio (11). Embrio akan berkembang bila suhu udara di sekitar telur minimal $21,11^{\circ} \mathrm{C}$ dan suhu terbaiknya adalah berkisar diantara $38^{\circ} \mathrm{C}-40{ }^{\circ} \mathrm{C}[12]$.

Pada umumnya dipasaran tersedia mesin penetas telur dengan satu sumber tenaga yaitu menggunakan tenaga listrik, maka dari itu kami membuat mesin penetas dengan menggunakan dua sumber tenaga yaitu menggunakan sumber tenaga dari panas sinar matahari di waktu siang hari dan menggunakan sumber tenaga listrik PLN pada malam hari. 


\section{METODOLOGI PENELITIAN}

Mesin penetas telur tenaga hybrid dirancang menggunakan dua sumber energi yaitu sumber listrik dari PLN dan sumber energy dari matahari. Proses rancang bangun mesin penetas telur tenaga hybrid dilaksanakan pada bulan februari sampai juli 2019. Lokasi pembuatan rancang bangun mesin penetas telur bertempat di laboratorium yang ada di Rumpun Teknik Mesin FT Universitas Negeri Jakarta. Proses diawali dengan studi literatur kemudian dilanjutkan dengan pembuatan sketsa gambar. Setelah gambar sketsa selesai kemudian dilanjutkan dengan proses perhitungan kebutuhan listrik, kebutuhan solar cell, kebutuhan baterai. Setelah semua perhitungan selesai kemudian dilanjutkan dengan pembuatan gambar kerja serta wiring kelistrikan. Langkah terakhir yaitu proses pembuatan dari mesin tetas.

\section{HASIL DAN PEMBAHASAN}

\section{Perhitungan Kebutuhan Listrik}

Untuk menghitung kebutuhan listrik diperlukan data awal yaitu volume mesin tetas, massa jenis udara, kalor jenis udara dan temperatur penetasan dalam hal ini peneliti menetapkan $37^{\circ}-38^{\circ}$.

Tabel 1. Data awal penentuan kebutuhan listrik

\begin{tabular}{|l|l|}
\hline \multicolumn{1}{|c|}{ Parameter } & \multicolumn{1}{c|}{ Nilai } \\
\hline Massa jenis udara $(\rho$ Udara) & $1.2 \mathrm{~kg} / \mathrm{m}^{3}$ \\
\hline Kalor jenis udara $(\mathrm{c})$ & $1000^{\circ} \mathrm{J} / \mathrm{Kg}^{\circ} \mathrm{C}$ \\
\hline Temperatur awal (T1) & $37^{\circ} \mathrm{C}$ \\
\hline Temperatur akhir $(\mathrm{T} 2)$ & $38^{\circ} \mathrm{C}$ \\
\hline Panjang Kotak $(\mathrm{P})$ & $0.63 \mathrm{~m}$ \\
\hline Lebar Kotak $(\mathrm{L})$ & $0.52 \mathrm{~m}$ \\
\hline Tinggi Kotak (t) & $0.48 \mathrm{~m}$ \\
\hline Volume (Vin) & $0.1572 \mathrm{~m}^{3}$ \\
\hline
\end{tabular}

Perhitungan Energi yang dibutuhkan inkubator penetas telur ayam untuk menjaga temperatur kerjanya pada $37^{\circ}-38^{\circ}$ adalah sebagai berikut :

$$
\begin{aligned}
& \mathrm{m}=\rho U \text { dara } \times \text { Vin } \\
& \mathrm{m}=1.2 \times 0.1572 \\
& \mathrm{~m}=0.1886 \mathrm{Kg}
\end{aligned}
$$

$\mathrm{Q}=\mathrm{m} . \mathrm{c} \cdot \Delta \mathrm{T}$

$\mathrm{Q}=0.1886 \times 1000 \times 1$

$\mathrm{Q}=188.6$ Joule

Perhitungan daya pemanas yang dibutuhkan dari temperatur awal (T1) ke temperatur akhir (T2) dibutuhkan selama 11 detik

$$
\begin{aligned}
& \mathrm{P}=\frac{\mathrm{W}}{\mathrm{t}} \\
& \mathrm{P}=\frac{188.6}{11} \\
& \mathrm{P}=17.14 \text { Watt } \approx 20 \text { Watt }
\end{aligned}
$$

Jika akan digunakan lampu pijar dengan daya 5 watt, maka diperlukan sebanyak 4 buah lampu pijar.

\section{Perhitungan Kebutuhan Sollar Cell}

Untuk mengetahui jumlah solar cell yang dibutuhkan, dilakukan perhitungan total kebutuhan daya (total beban) alat penetas telur :

Tabel 2 Perhitungan total kebutuhan daya

\begin{tabular}{|l|c|c|c|c|}
\hline \multicolumn{1}{|c|}{ Komponen } & $\begin{array}{c}\text { Waktu } \\
\text { (Jam) }\end{array}$ & Daya (Watt) & Jumlah & $\begin{array}{c}\text { Total Energi } \\
\text { Listrik (Wh) }\end{array}$ \\
\hline Lampu Pijar & 11 & 5 & 4 & 220 \\
\hline Thermostat & 24 & 0.035 & 1 & 0.84 \\
\hline Inverter & 24 & 0.42 & 1 & 10.08 \\
\hline Solar Controller & 12 & 3.6 & 1 & 43.2 \\
\hline \multicolumn{4}{|l|}{ Total Energi Listrik Per hari } & 274.12 \\
\hline
\end{tabular}


Perhitungan kebutuhan solarcell dengan energi total yang di bebankan dengan penggunaan solar cell dengan beban daya dengan satuan Watt Peak (Wp). Watt Peak merupakan daya maksimal yang di hasilkan oleh panel surya maka data digunakan perhitungan sebagai berikut :

$$
\text { Jumlah Daya }=\frac{\text { Etotal }}{\mathrm{Km}}=\frac{274.12}{4.31}=63.60 \mathrm{Wp}
$$

Dimana :

Etotal $=$ Energi Total

$\mathrm{Km} \quad=$ Insolasi matahari di Indonesia 4.31 (pada tahun 2012-2017)

Dari hasil perhitungan di atas dibutuhkan daya solarcell $63.60 \mathrm{Wp}$. Kapasitas panel surya yang digunakan adalah $100 \mathrm{Wp}$.

$$
\begin{aligned}
& \text { Jumlah Solarcell }=\frac{\text { Jumlah Daya }}{\text { Kapasitas Panel }} \\
& \text { Jumlah Solarcell }=\frac{63.60}{100}=0.636 \approx 1 \text { buah }
\end{aligned}
$$

Diperlukan 1 buah panel surya dengan tenaga 100Wp.

\section{Perhitungan Kebutuhan Baterai}

Baterai yang digunakan untuk menyuplai inkubator penetas telur ayam adalah menggunakan baterai tegangan 12 V dengan kapasitas 30 Ah. Asumsi pemakaian baterai dengan DOD ( Deef of Charge) 0.8 (Taufik, 2010), maka :

$$
\mathrm{Bc}=\frac{\text { Etotal }}{\mathrm{V}}=\frac{274.12}{12}=22.84 \mathrm{Ah}
$$

(6)

$\mathrm{Cb}=\frac{\mathrm{Bc}}{\mathrm{DOD}}=\frac{22.84}{0.8}=28.55 \mathrm{Ah}$

Dimana :

$\mathrm{Bc}=$ Kapasitas baterai $(\mathrm{Ah})$

$\mathrm{Cb}=$ Kapasitas baterai mempertimbangkan DOD (Ah)

$\mathrm{DOD}=$ Deep of Discharge $(0.8)$

Etotal $=$ Energi Total Keseluruhan

Jumlah Baterai $=\frac{\mathrm{Cb}}{\text { Nilai kapasitas baterai }}=\frac{28.55}{30}=0.95 \approx 1$ Baterai

\section{Pembuatan Gambar Wiring Kelistrikan}

Berikut adalah gambar wiring kelistrikan :

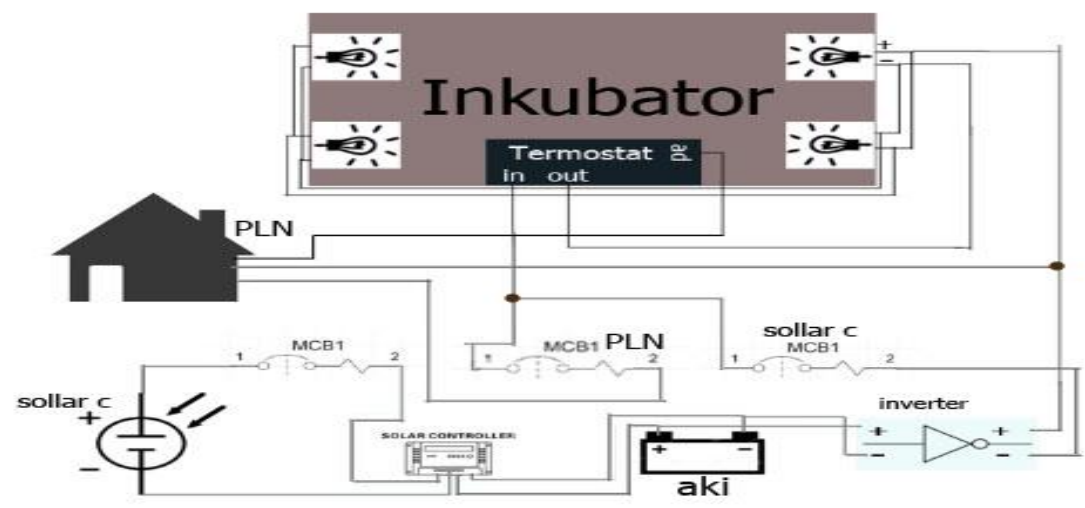

Gambar 1. Wiring kelistrikan 


\section{Pembuatan Gambar Kerja}

Mesin penetas telur memiliki komponen sekitar 30 jenis. Gambar mesin penetas dapat dilihat sebagai berikut.

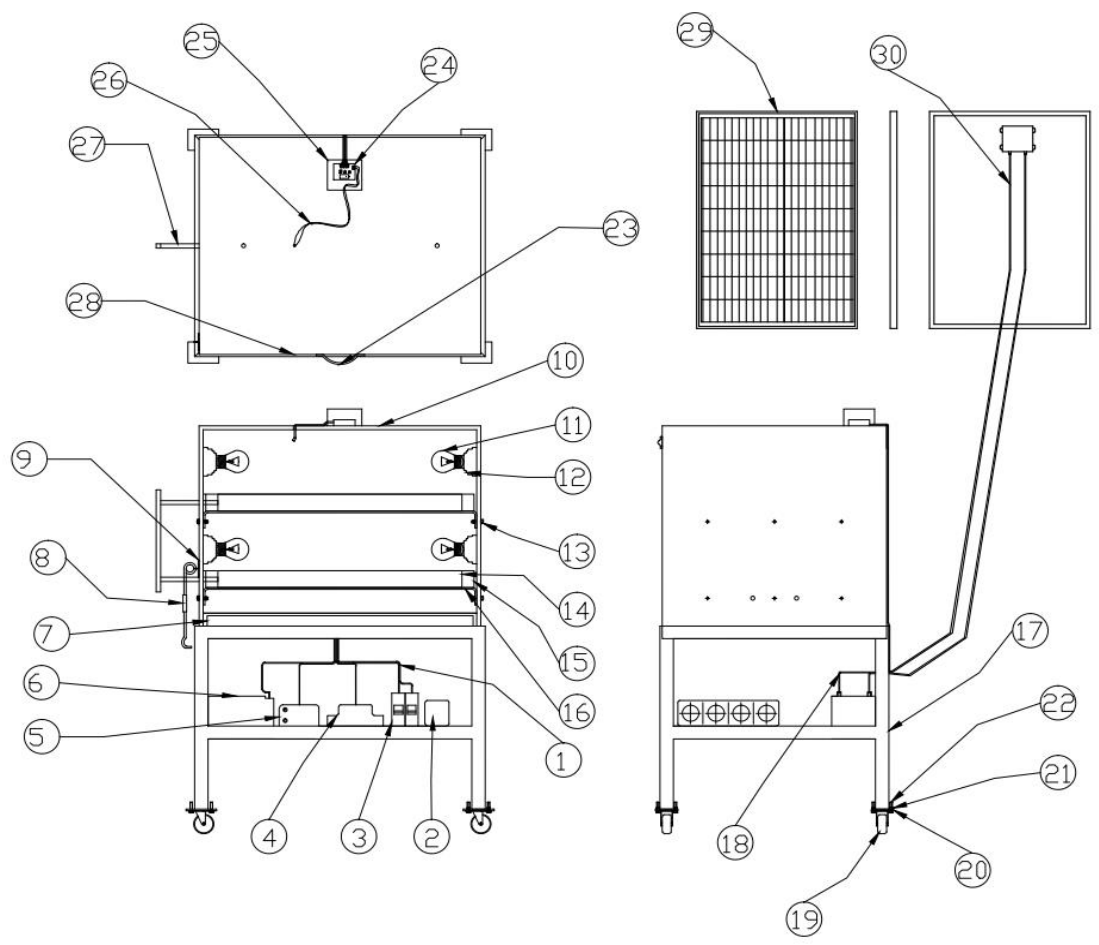

Gambar 2. Desain Mesin Tetas Telur

\begin{tabular}{|c|c|c|c|}
\hline No & Keterangan & No & Keterangan \\
\hline 1 & Kabel & 16 & Plat dudukan rak \\
\hline 2 & Saklar & 17 & Rangka \\
\hline 3 & MCB & 18 & Kabel Baterai \\
\hline 4 & Solar Charge controller & 19 & Roda \\
\hline 5 & Power Inverter & 20 & Plat \\
\hline 6 & Baterai Aki & 21 & Mur \\
\hline 7 & Plat Penampung Aki & 22 & Baut \\
\hline 8 & Pengait Pintu & 23 & Gagang Pintu \\
\hline 9 & Engsel Pengait Pintu & 24 & Thermostat \\
\hline 10 & Inkubator & 25 & Cover Thermostat \\
\hline 11 & Lampu Pijar & 26 & Kabel Thermostat \\
\hline 12 & Fitting Lampu & 27 & Tuas Rak \\
\hline 13 & Baut & 28 & Pintu \\
\hline 14 & Rak pembatas Telur & 29 & Solar Cell \\
\hline 15 & Rak Telur & 30 & Kabel Solar Cell \\
\hline
\end{tabular}




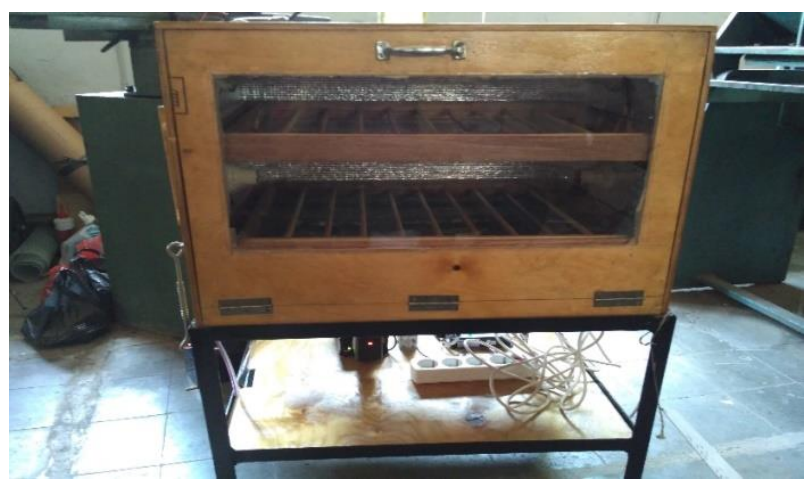

(a)

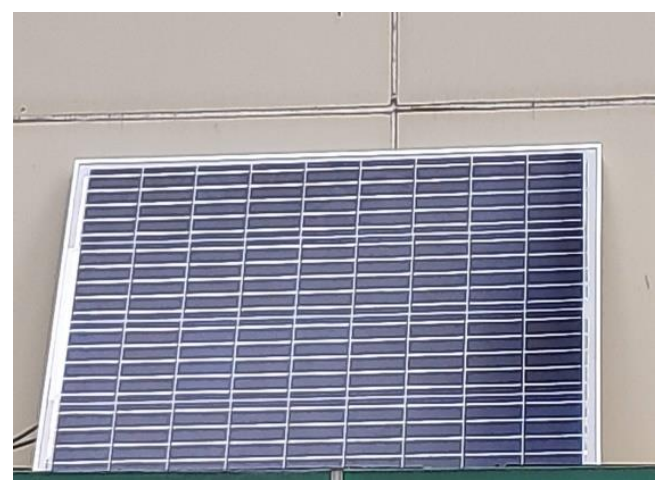

(b)

Gambar 3. Perangkat (a) Mesin Tetas dan (b) Panel Solar Cell

\section{Pengujian Kestabilan Temperatur}

Setelah Mesin Penetas Telur Tenaga Hybrid sudah selasai di Assembly dan Finishing, Mesin Penetas Telur Tenaga Hybrid sudah dapat melakukan tahap pengujian. Dalam pengujian Mesin Penetas Telur Tenaga Hybrid ini dialiri oleh sumber tenaga Listrik PLN dan juga sumber tenaga Panas Matahari, panas yang ada didalam Inkubator menggunakan 4 buah lampu bohlam dengan daya 20 watt. Pengujian yang dilakukan rentang waktu mulai pukul 13.00 - 14.40 WIB. Berikut adalah data selama 1 minggu pengujian Mesin Penetas Telur Tenaga Hybrid:

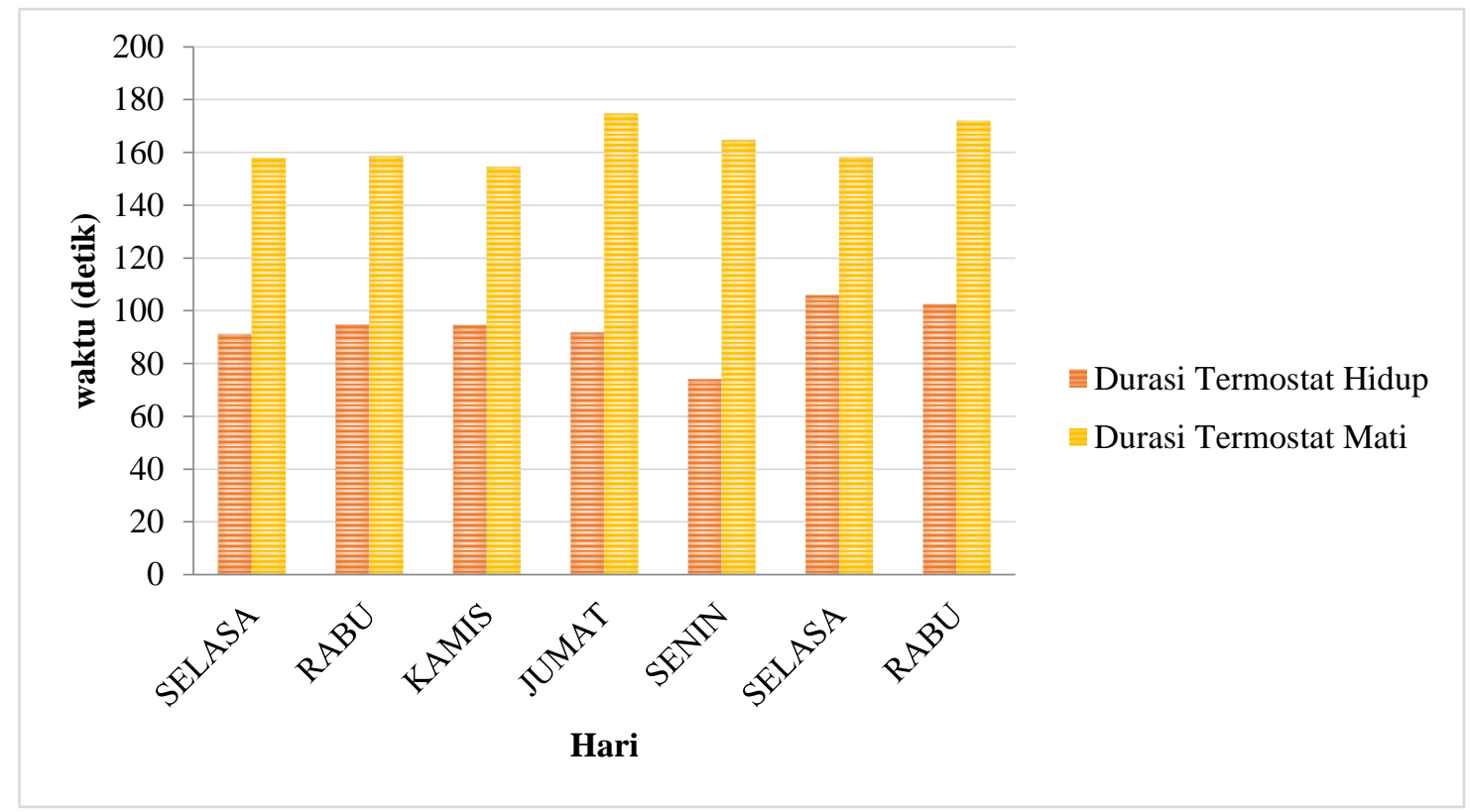

Gambar 4. Grafik menggunakan tenaga listrik

Pada gambar diatas dapat terlihat durasi termostat hidup dan mati ketika menggunakan sumber tenaga listrik. Pada saat pengujian temperatur pada termokontrol diatur $37^{\circ}-38^{\circ} \mathrm{C}$. Dari hasil pengamatan selama satu minggu terlihat temperatur yang terbaca pada termokontrol stabil sesuai yang diharapkan. 


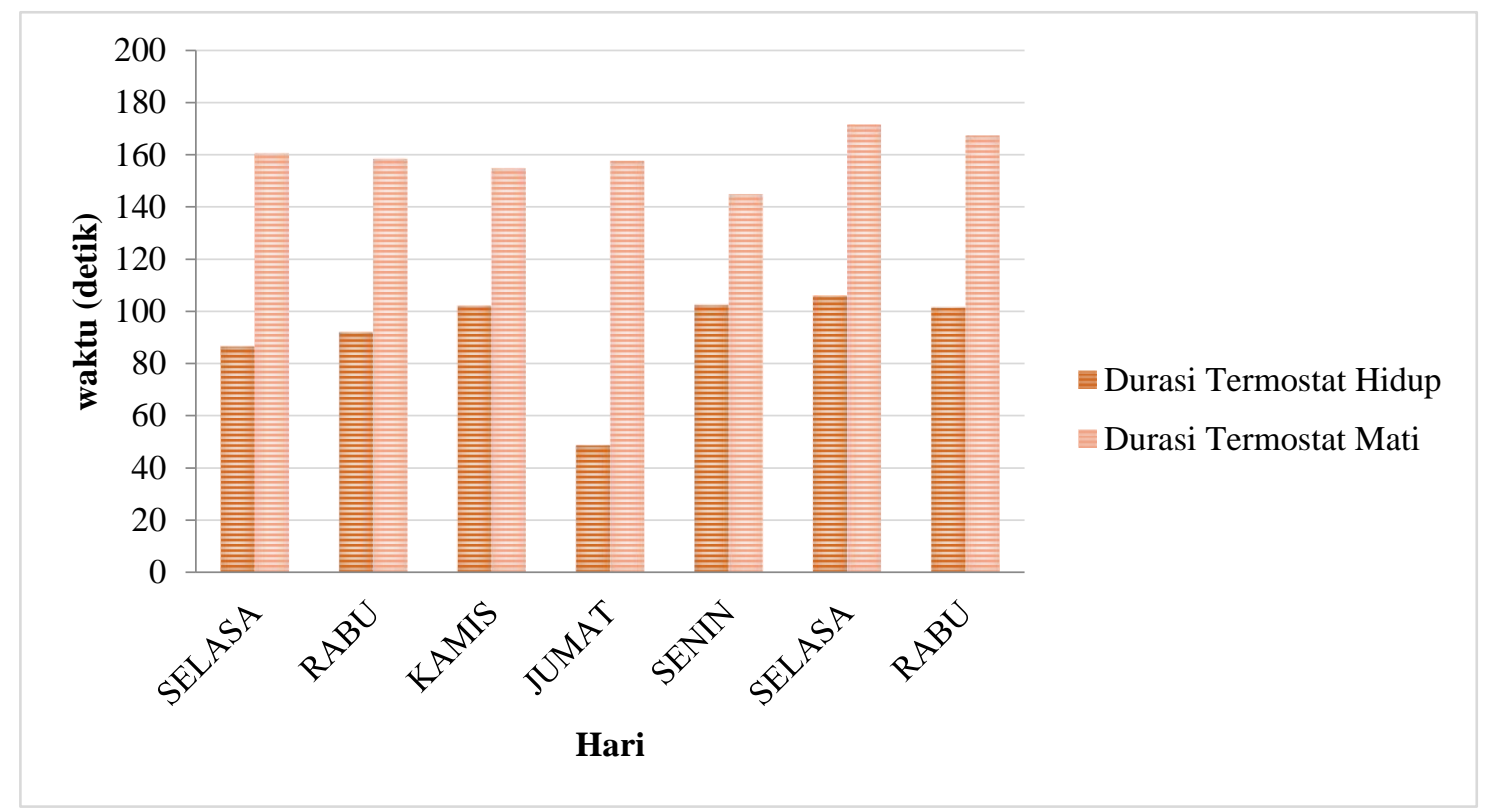

Gambar 5. Gambar grafik menggunakana tenaga panas matahari

Pada gambar diatas dapat terlihat durasi termostat hidup dan mati ketika menggunakan sumber tenaga panas matahari (solar cell). Pada saat pengujian temperatur pada termokontrol diatur $37^{\circ}-38^{\circ} \mathrm{C}$. Dari hasil pengamatan selama satu minggu terlihat temperatur yang terbaca pada termokontrol stabil sesuai yang diharapkan.

\section{KESIMPULAN}

Dari hasil pengujian yang dilakukan mesin Penetas Telur Tenaga Hybrid dapat berfungsi dengan baik menggunakan sumber energi matahari dan sumber listrik PLN. Suhu stabil pada Mesin Penetas Telur Tenaga Hybrid ini antara $37^{\circ}-38^{\circ} \mathrm{C}$.

\section{DAFTAR PUSTAKA}

1. https://www.bps.go.id/statictable/2014/09/08/950/rata-rata-konsumsi-per-kapita-seminggubeberapa-macam-bahan-makanan-penting-2007-2017.html diunduh tanggal 06 Oktober 2019

2. Muryanto, S., Yuwono, D. M., \& Dirdjopranoto, W. (1994). Optimalisasi produksi telur ayam buras melalui perbaikan pakan dan tata laksana pemeliharaan. J Ilmu Penelitian Ternak Klepu, 1, 9-14.

3. Paimin, Farry. 2000. Membuat Dan Mengelola Mesin Tetas. Penebar Swadaya. Jakarta.

4. Suprijatna, E., Umiyati A., dan Ruhyat K. 2008. Ilmu Dasar Ternak Unggas. Halaman 94. Penebar Swadaya. Jakarta.

5. Rusdin, M., \& Aku, A. S. (2014). Daya tetas dan lama menetas telur ayam tolaki pada mesin tetas dengan sumber panas yang berbeda. Jurnal Ilmu dan Teknologi Peternakan Tropis, 1(1), 32-44.

6. Kartasudjana, R., 2001. Penetasan Telur. Proyek Pengembangan Sistem dan Standar Pengelolaan SMK. direktorat Pendidikan Menengah Kejuruan. Departemen Pendidikan Nasional. Jakarta.

7. Ramli, M. B., Lim, H. P., Wahab, M. S., \& Zin, M. F. M. (2015). Egg hatching incubator using conveyor rotation system. Procedia Manufacturing, 2, 527-531.

8. Nurhadi, I., \& Puspita, E. (2009). Rancang Bangun Mesin Penetas Telur Otomatis Berbasis Mikrokontroler ATMega8 Menggunakan Sensor SHT11. Eepis final project.

9. Meijerhof, R. 2009. Incubation principles: What does the embryo expect from us? Pages 106-111 in Proc. 20th Australian Poultry Science Symp.

10. Ningtyas, M. S., Ismoyowati, I., \& Sulistyawan, I. H. (2013). Pengaruh Temperatur Terhadap Daya Tetas Dan Hasil Tetas Telur Itik (Anas Plathyrinchos)(The Effect Of Temperature On Hatchability And Egg Hatching Yield Duck (Anas platyrinchos)). Jurnal Ilmiah Peternakan, 1(1). 
11. Elsayed, N.A.M, Allan E.E., Amina S.E., dan Effet Y.Hassan. 2009. New Suggested Schemes for Incubation Temperature and Their Effect on Embryonic Development and hatching Power. Poultry Science, 3(1) : 19-29.

12. Suprapto, Tjahjono, A., Sunarno, E. (2010). Rancang Bangun Mesin Penetas Telur Ayam Berbasis Mikrokontroler dengan Fuzzy Logic Controller (Software). Dipetik 6 Oktober 2019, dari http://digilib.its.ac.id/public/ITS-NonDegree-8175-7306030054_paper.pdf 